\title{
An Analysis of Landslide Occurrence Distribution and Geomorphological Conditions of Arus River Sub-Watershed in Banyumas Regency
}

\author{
Suwarno \\ Universitas Muhammadiyah Purwokerto \\ suwarnohadimulyono@gmail.com
}

\begin{abstract}
Landslide occurrences are caused by internal and external factors. The internal factors comprise geological, morphological and soil conditions. Meanwhile, the external factors cover land use and human activities in land management. This research aims to review distributions of landslide occurrences along with geomorphological conditions in the research areas. This research applied the survey method using landform units as the approach. The sampling technique was incidental sampling. The data included all landslide points, slopes and rocks. The data were analyzed by using a multi-layered map and a frequency table. The research showed originalthe landform structures in the research areas. The Geological structure found was synclinal folds and diagonal layers in which 48 landslides occurred and were randomly found. The highest landslide occurrence frequency was found in the slope class III and on the landform unit of the hill structure with the slope class III and on the formation of Halang rock formation.
\end{abstract}

Keywords: occurrence, landslide, landform

\section{INTRODUCTION}

From the geological perspective, Indonesia is an archipelago nation which was formed througha plunge of three major plates of Earth. Those three plates are HindiaAustralia, Pacific Ocean, and Eurasian continent. As those three plates plunge, it results in the manifestation of volcanic tracks, earthquakes, geological structures, morphological differences, and mountain tracks. Therefore, the Indonesian archipelago is not stable. This instability leads to several natural disasters including landslides. Landslides occurrence and density can be influenced by morphological and geological conditions [1].

Geomorphology is a branch of science concerning with landforms on the earth's surface with an emphasize on natural characteristics, development process, constructions of material compositions, as well as correlations among the processes and landforms[2].Geomorphology is also defined as a branch of science describing landforms and the process as well as investigating correlations among landforms and processes in a spatial structures[3]. Landformsare a manifestation of fields which were formed by the natural process possessing certain compositions and physical characteristics, as well ascontinuous physical characteristics and visuals [4]. The process of geomorphology comprises exogenic and endogenic processes One example of exogenic process is mass movements.

Mass movements may occur in all areas especially those with the topography of hills and mountains. There are two factors influencing mass movements consisting of passive and active causes [5].Active causes are human activities in managing their land while passive causes comprise lithology, stratigraphy, structures, topography, climates, organism, and earthquakes. One of mass movement forms is landslides[6].

Landslides often occur on structural landform units composed of sandstone and tuff onsteep slopes[7]-[8]. High frequency landslide occurrences possessing high density can be found on the wavy foots of slopes that are considered moderate and strong, volcanic landforms of upper slopes as well as sides of ravines and volcanic cones. Sediment tertiary materials of combined sand and clay possess the highest sliding intensity [9]-[10]. High density and frequency of a landslide occur during monthly average rainfall volume at a long period [11]. The highest frequency of landslide occurrences was at the rainfall volume at $250-350 \mathrm{~mm} /$ month [12]-[13].

Sub-watershed of Arus river is flowing on the track of north Serayu mountain and emptying on Tajum river. This sub-watershed in terms geomorphology conditions is in the form of structural formation composed of sediment rock at tertiary age constructed from free volcanic materials such as lava, andesite sand, clay, tuff and others. Landslides will mostly be encountered in the area with such conditions as found in the steep slopes [14]-[15]. An area composed of free materials such as volcanic lava andesite and sediment rock at the tertiary age possess high vulnerability to landslides [16]. Landslides themselves are a form of mass of movements[17]. This research aims to review the distribution of landslides with the geomorphological 
conditions in the sub-watershed of Arus River. Furthermore, it also aims to review the distribution of landslide occurrences with the geomorphological conditions.

\section{METHOD}

The method used in this research was field survey. The steps comprised pre-field, mid-field and post-field. The pre-field stage covered observation and land slide mapping. The mid-field stage comprised observation of landslide occurrences as well as finding the coordinates of landslides. Meanwhile, the sampling technique used in this research was incidental sampling. The post field survey was carried out through data interpretation and analysis. The data were all coordinate points in all landslide locations, slopes, and rocks. Data analysis implemented multi-layered maps and frequency tables. Descriptive quantitative was used in analyzing data.

\section{RESULT AND DISCUSSION}

\section{Research area description}

The research areas are located inthe sub-area of watershed of Arus river which is administratively located in both Gumelar and Pekuncen districts in Banyumas regency. The astronomical position of the research areasare on Latitude $7^{0} 20^{\prime} 20,83^{\prime \prime}-7^{0} 24^{\prime} 30,56^{\prime \prime} \mathrm{S}$ andequator $109^{0}$ $00^{\prime} 21,52^{\prime \prime}-109^{\circ} 03^{\prime} 34,21^{\prime \prime}$ E. the geographical position of Arus River sub-watershed is located in Banyumas regency flowing upstream on the north (the peak of Serayu hills) towards downstream on the south (flowing in Tajum river), the landform of Arus River sub-watershed derives from the original structural landform.

The research areas in terms of geomorphology are in the subzone of north Serayu mountain in the center zone of Java island. According to the origin of landform formation, the research area is in the category of the original structural landform. The original structural landform is resulted from the endogenic process and its rock structure is layered. Structural landformsare characterized by the existence of sloping alteration of rock layering. In the early stage, the original layer of rock is flat. The occurrence of Endogenic process causes rock layers to slop or shift. The identification of original structural landforms is based on the topography by identifying contour patterns, geological maps and field observation results. Topography is an appropriate guidance to predict the geological structures[15].

\section{The distribution of landslide occurrences with geomorphological conditions}

The correlation between geomorphology and landslide occurrences can be explained by analyzing the slopes and landform units in the research areas. The distribution of landslide occurrences is not equal in every slope. The highest frequency of landslide occurrences could be found on the slope $15-25 \%$ (class III) with total number of $47.92 \%$ out of the total frequency of landslides. It is in contrast with the result of research [6] stating that landslideswere concentrated on slopes class IV (25 - <45\% or steep) with total number of pf 53 or $54.08 \%$. Meanwhile, it is in line with research result [16][17]. On slopes class IV and $\mathrm{V}$, the landslide occurrences frequency is lower than those of class III. It is caused by the condition of slopes class IV and $\mathrm{V}$ which resulted on a higher frequency of surface erosion. Thus, the thinner soil solumcauses lower weight of slopes. The correlation between the slope class and landslides is presented on Table 1.

Table 1: The correlation between the slope class and the frequency of landslide occurrences.

\begin{tabular}{ccccr} 
no & slope class & $\begin{array}{c}\text { width } \\
\text { (ha) }\end{array}$ & \multicolumn{2}{c}{ landslide points } \\
\cline { 4 - 5 } & & & number & percentage \\
\hline 1 & $0-8 \%$ & 70.75 & 2 & 4.17 \\
2 & $8-15 \%$ & 244.32 & 3 & 6.25 \\
3 & $15-25 \%$ & 567.82 & 23 & 47.92 \\
4 & $25-40 \%$ & 883.94 & 11 & 22.92 \\
5 & $\geq 40 \%$ & 262.96 & 9 & 18.75 \\
TOTAL NUMBER & 2029.78 & 48 & 100.00
\end{tabular}

The rocks from the top to the bottom in research areas due to geological reading in the western part comprises Halang formation (Tmph), and Tapak formation (Tpt). Halang formation at the tertiary period (mid-end miosen) is composed of sandstone, andesite, tuff, brexy, and napal, which is inserted in sandstone. Tapak formation at the tertiary period (pliosen) is composed of sandstone with greenish rough granules, napal limestone, tuff limestone and greenish napal.

Geological structures in the research areas consist of synclinal folds and diagonal layer structures. Synclinal folds are found in theupstream of Arus River with the Tapak (Tpt)rock formation. The sloping layers can be found in all research areas.In general, this sloping layers emerge in Halang formation(Tmph). Landslide occurrences mostly happen in Halang formation at $57 \%$ of the overall occurrences. The frequency of landslide occurrences in each rock formation is presented in the following Table 2 . 
Table 2: The landslide occurrence in each rock formation

\begin{tabular}{|c|c|c|c|c|}
\hline \multirow[t]{2}{*}{ NO } & \multirow[t]{2}{*}{ GEOLOGY } & \multirow{2}{*}{$\begin{array}{l}\text { WIDTH } \\
\text { (ha) }\end{array}$} & \multicolumn{2}{|c|}{ LANDSLIDE POINTS } \\
\hline & & & Number & Percentage \\
\hline 1 & $\begin{array}{l}\text { Halang } \\
\text { formation }\end{array}$ & 1465.31 & 26 & 54.17 \\
\hline 2 & $\begin{array}{l}\text { Tapak } \\
\text { formation }\end{array}$ & 564.47 & 22 & 45.83 \\
\hline & Total & 2029.78 & 48 & 100.00 \\
\hline
\end{tabular}

There are seven landform units that could be found on the research areas. The distribution of landslide occurrencesis not equal on all landform units. The highest frequency of landslide occurrences could be found on the structural hillson the slope class III with the total frequency of $29.17 \%$. The correlation between landform units and the frequency of landslide occurrences is presented on Table 3. It is in line with the research [18] stating that the highest frequency of landslide occurrences is on the structural landform unit. Theyare caused by the periods, large number of cracks, and sloping layer position which in line with the slope. In the original structural of landform units, the surface of the topography is rough. This finding is supported by [18] stating that landslide occurrences are highly correlated with the roughness of topography.

Table 3: Correlation of landform units with the frequency of landslide occurrences

\begin{tabular}{|c|c|c|c|c|}
\hline \multirow[t]{2}{*}{$\mathrm{z}$} & \multirow[t]{2}{*}{ LANDFORM } & \multirow[t]{2}{*}{$\begin{array}{l}\text { WIDTH } \\
\text { (ha) }\end{array}$} & \multicolumn{2}{|l|}{$\begin{array}{l}\text { LANDSLIDE } \\
\text { POINTS }\end{array}$} \\
\hline & & & Number & $\%$ \\
\hline 1 & $\begin{array}{l}\text { Hilly valley of } \\
\text { structural slope I }\end{array}$ & 70.75 & 2 & 4.17 \\
\hline 2 & $\begin{array}{l}\text { Synclinal hills of slope } \\
\text { III }\end{array}$ & 94.79 & 9 & $\begin{array}{r}18.7 \\
5\end{array}$ \\
\hline 3 & $\begin{array}{l}\text { Synclinal hills of slope } \\
\text { IV }\end{array}$ & 24.97 & 0 & 0,00 \\
\hline 4 & $\begin{array}{l}\text { Synclinal hills of slope } \\
\text { V }\end{array}$ & 29.20 & 1 & 2,08 \\
\hline 5 & $\begin{array}{l}\text { Synclinal hills of slope } \\
\text { II }\end{array}$ & 244.32 & 3 & 6.25 \\
\hline 6 & $\begin{array}{l}\text { Synclinal hills of slope } \\
\text { III }\end{array}$ & 551.45 & 14 & $\begin{array}{r}29.1 \\
7\end{array}$ \\
\hline 7 & $\begin{array}{l}\text { Synclinal hills of slope } \\
\text { IV }\end{array}$ & 780.54 & 11 & $\begin{array}{r}22.9 \\
2\end{array}$ \\
\hline 8 & $\begin{array}{l}\text { Synclinal hills of slope } \\
\text { V }\end{array}$ & 233.76 & 8 & $\begin{array}{r}16.6 \\
7\end{array}$ \\
\hline TOTAL & 2029.78 & 48 & 100.00 & \\
\hline
\end{tabular}

\section{CONCLUSION}

This research leads to a conclusion thatthe morphography of the research areas consists of lands, valleys, and hills. The slopesranging from class Itoclass $\mathrm{V}$ with class IV as the widest class. The land formunitsconsist of original structural landforms and are divided into 8 land formunits. Land form occurrences spread unequally on all researcher eas. The highest frequency of lands lide occurrencescanbe found in slopes class III, land formunit of structural hills as well as slope sclass III and on Halang formation. Halang formationis composed of rocks at tertiary period (middle - final Miosen) such as and esites and stone, tuff, brexy, and napal inserted in sandstone. The secharacteristics result in high frequency of lands lides as this is also supported by sloping rock layers.

Note: The since rest gratitude is presented to general directorate of DRPM of the Indonesian Ministry of Research, Technology, and Higher Education forgiving the support by providing funding for this research

\section{REFERENCES}

[1.] H. B. Havenith, A. Torgoev, R. Schlögel, A. Braun, I. Torgoev, and A. Ischuk, "Tien Shan Geohazards Database: Landslide susceptibility analysis," Geomorphology, vol. 249, pp. 32-43, 2015.

[2.] A. Suharini, E., dan Palangan, "Geomorfologi: Gaya, Proses, dan Bentuklahan, Ombako Title," Ilmu Tanah dan Lingkung., vol. 2, pp. 7-16, 2014.

[3.] Z. C. Zuidam, "Terrain Analysis and Classification Using Aerial Photograph Interpretation," vol. VII, no. Enschede, The Netherlands, p. 6, 1978.

[4.] S. Worosuprojo, "Studi Erosi Parit dan Longsoran dengan Pendekatan Geomorfologis di Daerah Aliran Sungai Oyo Provinsi Daerah Istimewa Yogyakarta," Desertasi S3, 2002.

[5.] Thornbury, "Principles of Geomorphology," 1954.

[6.] Suwarno, "Model Pengelolaan lahan pada Wilayah Rawan Longsorlahan di Kecamatan Pekuncen Kabupaten Banyumas," Disertasi, Progr. Dr. Fak. Geogr. Univ. Gadjah Mada Yogyakarta, 2014.

[7.] K. Roback et al., "The size, distribution, and mobility of landslides caused by the 2015 Mw7.8 Gorkha earthquake, Nepal," Geomorphology, vol. 301, pp. 121-138, 2018.

[8.] B. Barus, "Pemetaan Bahaya Longsoran Berdasarkan Klasifikasi Statistik Peubah Tunggal Menggunakan SIG: Studi Kasus Daerah Ciawi Pincak - Pacet, Jawa Barat," Ilmu Tanah dan Lingkung., vol. 2 No 1, pp. 7-16, 1999. 
[9.] C. Arifin, S., Carolila, I.dan Winarco, "Implementasi Penginderaan Jauh dan SIG Untuk Inventarisasi Daerah Rawan Bencana Longsor Provinsi Lampung," Penginderaan Jauh, vol. 3 No 1, pp. 77-86, 2006.

[10.] L. Borrelli, L. Antronico, G. Gullà, and G. M. Sorriso-Valvo, "Geology, geomorphology and dynamics of the 15 February 2010 Maierato landslide (Calabria, Italy)," Geomorphology, vol. 208, no. February 2010, pp. 50-73, 2014.

[11.] Y. S. Kuo, Y. J. Tsai, Y. S. Chen, C. L. Shieh, K. Miyamoto, and T. Itoh, "Movement of deep-seated rainfall-induced landslide at Hsiaolin Village during Typhoon Morakot," Landslides, vol. 10, no. 2, pp. 191-202, 2013.

[12.] P. Carrara, A., Crosta, G., and Frattini, "Geomorphological and Historical Data in Assessing Landslide Hazard," Earth Surf. Process. Landforms, Earth Surf, Process. Landforms, vol. 28, pp. 1125-1142, 2003.

[13.] R. A. C. Z`ezere, J.L., Trigo, R. M., Fragoso, M., Oliveira, S. C., and Garcia, "Rainfall-triggered landslides in the Lisbon region over 2006 and relationships with the North Atlantic Oscillation," Nat. Hazards Earth Syst. Sci., vol. 8, pp. 483-499, 2008 .
[14.] E. Borgomeo, K. V. Hebditch, A. C. Whittaker, and L. Lonergan, "Characterising the spatial distribution, frequency and geomorphic controls on landslide occurrence, Molise, Italy," Geomorphology, vol. 226, pp. 148-161, 2014.

[15.] R. J. Barnes, J.W., and Lisle, Basic Geological Mapping. England: John Wiley \& Sons Ltd, The Atrium, Southern Gate,Chichester, West Sussex PO19 8SQ, 2004.

[16.] A. Knapen, A., Kitutu, M.G., Poesen, J., Breuggelmans, W., Deckers J., and Muwanga, "Landslides in A Densely Populated County At The Footslopes of Mount Elgon (Ugnda): Characterstics and Causal Factors," Geomorphology, vol. 73, pp. $149-165,2005$.

[17.] J. A. Coe, J.A., Godt, J.W., Baum, R.L., Bucknam, R.C., and Michael, "Landslide Susceptibility From TopographyTopography in Guatemala," Landslides Eval. Stab., vol. I, no. W.A. Lacerda, M. Ehrlich, S.A.B. Fontura\& A.S.F. Sayao (eds) @ 2004 Taylor \& Francis Group, London, ISBN 0415356652, pp. 69-78, 2004.

[18.] J. D. Glenn, F.N., David, R.S., John, C.D., Glenn, D.T., and Stephen, "Analysis of LiDAR-derived Topographic Information for Characterizing Landslide Morphology and Activity," $J$. Geomorphol., vol. 73, pp. 131 - 148, 2006. 